\title{
Papillary Breast Carcinoma
}

National Cancer Institute

\section{Source}

National Cancer Institute. Papillary Breast Carcinoma. NCI Thesaurus. Code C9134.

A breast carcinoma characterized by the formation of irregular, finger-like projections of fibrous stroma covered with neoplastic epithelial cells. 